Article

\title{
Interaction between WC and Inconel 625 under Solid and Liquid State Sintering Conditions
}

\author{
Lorena Emanuelli *, Alberto Molinari and Massimo Pellizzari (ic \\ Department of Industrial Engineering, University of Trento, 38123 Trento, Italy; alberto.molinari@unitn.it (A.M.); \\ massimo.pellizzari@unitn.it (M.P.) \\ * Correspondence: lorena.emanuelli@unitn.it
}

\begin{abstract}
Cobalt is the most used metal binder in hard metals since its extraordinary wetting, adhesion and mechanical properties. Nevertheless, it has been recognized genotoxic and cancerogenic with higher toxicity in combination with WC. To substitute Co with an alternative binder, the interaction between the binder and WC must be taken into account. In this work, IN625 is considered as a binder alternative due to its desirable combination of high-temperature strength and corrosion/oxidation resistance. A characterization of the interaction between WC and IN625 was carried out by means of Scanning Electron Microscopy (SEM), Energy Dispersive X-Ray Spectroscopy (EDXS) and X-Ray Diffraction (XRD). Depending on the sintering temperatures, different phases were evidenced at the WC-IN625 superalloy interface. From $1250^{\circ} \mathrm{C}$ to $1300{ }^{\circ} \mathrm{C}$, where solid-state sintering takes place, $(\mathrm{Cr}, \mathrm{Mo})_{23} \mathrm{C}_{6}, \mathrm{~W}_{2} \mathrm{C}$ and $(\mathrm{Cr}, \mathrm{W})$ solid solutions were detected. At a sintering temperature of $1350{ }^{\circ} \mathrm{C}$, IN625 melts and the formation of additional phases, such as an intermetallic $\mathrm{Ni}_{4} \mathrm{~W}$ phase and (Mo,W) and $(\mathrm{Mo}, \mathrm{Nb})$ solid solutions, were observed. The precipitation of $\mathrm{NbC}$ and $(\mathrm{Mo}, \mathrm{Cr}){ }_{23} \mathrm{C}_{6}$ carbides in IN625 was also detected.
\end{abstract}

Citation: Emanuelli, L.; Molinari, A.; Pellizzari, M. Interaction between WC and Inconel 625 under Solid and Liquid State Sintering Conditions. Metals 2021, 11, 666. https://doi.org/ $10.3390 /$ met11040666

Academic Editors: Jose Torralba and Francisco Paula Gómez Cuevas

Received: 25 March 2021

Accepted: 16 April 2021

Published: 19 April 2021

Publisher's Note: MDPI stays neutral with regard to jurisdictional claims in published maps and institutional affiliations.

Keywords: sintering; tungsten carbide; Inconel 625; interface interaction; metal matrix composite

\section{Introduction}

WC-Co cemented carbides are the highest-performing tool materials due to their unique combination of hardness and toughness [1-3]. WC is the most used hard phase in cemented carbide due to its high hardness, appreciable plasticity and good wettability by liquid cobalt, which is fundamental to obtain a full density and a homogeneous distribution of the metallic binder after liquid phase sintering [1,4]. Even if Co is the most used metal binder in WC-Co due to its good mechanical properties and excellent wetting and adhesion, it has been recognized to be genotoxic and cancerogenic with higher toxicity in combination with WC [5]. Moreover, in applications where damage phenomena due to thermal fatigue, oxidation and corrosion may occur, a binder possessing a better high-temperature strength and corrosion/oxidation resistance than Co is necessary.

Many attempts have been made in the past to produce alternative cemented carbides with either complete or partial substitution of $\mathrm{Co}$ with $\mathrm{Ni}$, Fe or $\mathrm{Ru}$ or with additions of modifiers, such as $\mathrm{Ru}, \mathrm{Cr}$ or Mo [3,6-11]. The thermodynamic calculation of W-Ni-C and $\mathrm{W}$-Co-C demonstrates that the solidus temperature and the WC solubility in the liquid are lower for the Ni-based system [12]. Guillermet [13] calculated a vertical section of $\mathrm{W}-\mathrm{Ni}-\mathrm{C}$ at $10 \mathrm{wt} . \%$ of $\mathrm{Ni}$, obtaining a section similar to the one of W-Co-C at $10 \mathrm{wt} . \%$ of Co. In detail, the substitution of $\mathrm{Co}$ by $\mathrm{Ni}$ leads to the same width of the Ni-WC region but lower carbon content values. The increase in the $\mathrm{C}$ content in the WC-Ni region leads to a decreased melting temperature. Moreover, depending on the $\mathrm{C}$ content, the formation of a third phase, a $\mathrm{M}_{6} \mathrm{C}-\mu$ phase (low carbon) with graphite (high carbon), is predicted.

To obtain a hard metal with higher corrosion resistance, Motitschka et al. [14] studied the W-Co-Cr-C and W-Ni-Cr-C systems and measured the solubility of $\mathrm{Cr}$ in the solid binder. In $\mathrm{W}-\mathrm{Co}-\mathrm{Cr}-\mathrm{C}$, the maximum solubility is $5 \mathrm{wt} . \% \mathrm{Cr}$ at $1000{ }^{\circ} \mathrm{C}$, and a higher $\mathrm{Cr}$ content 
led to the precipitation of the $(\mathrm{Cr}, \mathrm{Co}, \mathrm{W})_{7} \mathrm{C}_{3}$ carbide. In contrast, the maximum solubility in $\mathrm{W}-\mathrm{Ni}-\mathrm{Cr}-\mathrm{C}$ was $7 \mathrm{wt} . \% \mathrm{Cr}$ and, exceeding this value, $\mathrm{Cr}_{3} \mathrm{C}_{2}$ carbide forms. Even if WC has a lower wettability by liquid $\mathrm{Ni}$ than by liquid $\mathrm{Co}$, and the solid solubility of WC into liquid $\mathrm{Ni}$ is not as high as for liquid $\mathrm{Co}, \mathrm{Ni}$ seems to be a good alternative to Co because its similar interaction with $W$ and $C[12,13]$, and because of higher temperature strength.

Furthermore, in applications where high amounts of binder are necessary, namely hot rolling, the addition of $\mathrm{Ni}$ to Co binder leads to improved toughness [8]. Moreover, the addition of $\mathrm{Cr}$ increases the corrosion resistance of the $\mathrm{W}-\mathrm{Ni}-\mathrm{C}$ system. For these reasons, nickel-based superalloys represent an interesting alternative binder in high temperature applications due to their excellent combination of high-temperature strength and corrosion/oxidation resistance [10,11].

IN625 is a nickel-chromium alloy characterized by its high strength, outstanding corrosion resistance and service temperature up to $980^{\circ} \mathrm{C}$. It is a solid solution strengthening $\mathrm{Ni}$ superalloy due to the presence of $\mathrm{Cr}$, Mo and $\mathrm{Nb}[15,16]$. It is also characterized by precipitation hardening when either $\gamma^{\mathrm{II}}-\mathrm{Ni}_{3} \mathrm{Nb}$, or a carbide like $\mathrm{MC}, \mathrm{M}_{6} \mathrm{C}$ and $\mathrm{M}_{23} \mathrm{C}_{6}$ precipitates are homogeneously distributed into the matrix [17]. Other intermetallic phases may create precipitates, including the $\delta-\mathrm{Ni}_{3} \mathrm{Nb}$ orthorhombic crystal structure and Laves $\mathrm{A}_{2} \mathrm{~B}$-type hexagonal crystal structure. In addition, nitrides such as $\mathrm{M}_{2} \mathrm{~N}$ with a tetragonal crystal structure were detected [16-22].

To the authors' knowledge, the chemical interaction between Ni superalloy and WC has been poorly studied until now. Some investigations have been carried out on a composite produced by additive manufacturing and laser cladding [23-26]. Many different phases were detected, including $\mathrm{WC}, \mathrm{W}_{2} \mathrm{C}, \mathrm{MC}, \mathrm{W}_{x} \mathrm{C}_{y}, \mathrm{M}_{23} \mathrm{C}_{6}, \mathrm{Ni}_{x} \mathrm{~W}_{y}, \mathrm{Ni}_{3} \mathrm{Nb}$ and Laves $\mathrm{A}_{2} \mathrm{~B}$-type. Huebner et al. [24] studied the grain boundary interaction between IN625 and WC during laser metal deposition and revealed the presence of two major phases: $\mathrm{Ni}_{0.85} \mathrm{~W}_{0.15}$ and $\mathrm{Ni}_{6} \mathrm{Mo}_{6} \mathrm{C}_{1.06}$, indicating that $\mathrm{WC}$ grains dissolve into the Ni matrix. Three different IN625 $(104 \mu \mathrm{m})-\mathrm{WC}(0.54 \mu \mathrm{m})$ composites with 10,20 and $30 \mathrm{wt} . \%$ of WC produced by powder laser cladding were investigated by Janicki and Musztyfaga [26]. Through XRD analysis, only $\mathrm{Ni}$ and WC were detected in IN625-WC with 10 and $20 \mathrm{wt} . \%$ of WC. In addition, $\mathrm{W}_{2} \mathrm{C}, \mathrm{NbC},(\mathrm{Nb}, \mathrm{W}) \mathrm{C}, \mathrm{W}_{6} \mathrm{C}_{2.54}$ and $(\mathrm{W}, \mathrm{Cr}, \mathrm{Ni})_{23} \mathrm{C}_{6}$ carbides were detected in the $30 \mathrm{wt} . \%$ WC composite. There is a paucity of research in terms of the production of WC-IN625 hard metals manufactured with the press and sinter technology.

The aim of this work is to investigate the interaction between WC and IN625 during sintering of a prior compacted powder. Large IN625 particles were used in order to obtain a wide and localized interface region to facilitate the analyses at the Scanning Electron Microscope (SEM). Conversely, the use of a fine/ultrafine Inconel powder, which is mandatory to achieve a homogeneous distribution of the metallic binder in the sintered microstructure, would result in a very thin and highly dispersed interface. A $70 \mathrm{wt} . \% \mathrm{WC}-$ $30 \mathrm{wt} . \%$ IN625 mix was processed by hot compaction and sintering at different temperatures. The high binder content was chosen to simulate the composition of hard metals for high temperature applications (e.g., hot rolls). It also helps in the investigation since it favors the formation of a large interface region between the two constituents. The microstructure and the phase constitution of samples were analyzed by Scanning Electron Microscopy (SEM), Energy Dispersive X-Ray Spectroscopy (EDXS) and X-Ray Diffraction (XRD).

\section{Materials and Methods}

Commercial WC and IN625 powders were used. The chemical composition of IN625 powder used in this study is summarized in Table 1.

Table 1. Chemical composition of the IN628 powder.

\begin{tabular}{ccccccccc}
\hline \multicolumn{10}{c}{ Chemical Composition of IN625 (wt. \%) } \\
\hline $\mathbf{N i}$ & $\mathbf{C r}$ & $\mathbf{M o}$ & $\mathbf{N b}$ & $\mathbf{F e}$ & $\mathbf{S i}$ & $\mathbf{M n}$ & $\mathbf{O}$ & $\mathbf{C}$ \\
\hline 64.81 & 21.30 & 8.90 & 3.58 & 0.42 & 0.41 & 0.38 & 0.06 & 0.01 \\
\hline
\end{tabular}


The average particle size of WC is $0.8 \mu \mathrm{m}$, while that of IN625 is in the range of 53-150 $\mu \mathrm{m}$. The powders were blended (70 wt.\% WC and $30 \mathrm{wt} . \%$ of IN625) using a Turbula mixer. Disc samples (D $20 \mathrm{~mm}, \mathrm{H} 10 \mathrm{~mm}$ ) were hot-compacted with a pressure of $60 \mathrm{MPa}$ at $950{ }^{\circ} \mathrm{C}$ for $5 \mathrm{~min}$ using a SPS-1050 system produced by Sumitomo Coal Mining Co. Ltd with punches covered by BN to avoid current flow through the powder. In this way, the powder was heated up only by conduction from the die.

A conventional sintering process in a tubular furnace was carried out in a $\mathrm{N}_{2}$ atmosphere, using a heating and cooling rate of $4{ }^{\circ} \mathrm{C} / \mathrm{min}$, and dwells of $30 \mathrm{~min}$ at $1250{ }^{\circ} \mathrm{C}$, $1275{ }^{\circ} \mathrm{C}, 1300^{\circ} \mathrm{C}$ and $1350{ }^{\circ} \mathrm{C}$. Temperatures were selected from the results of a Differential Temperature Scanning Calorimeter (DTSC) analysis. It was carried out in a $\mathrm{N}_{2}$ atmosphere with a heating rate of $10^{\circ} \mathrm{C} / \mathrm{min}$ up to $1400{ }^{\circ} \mathrm{C}$.

The sintered samples were observed by SEM after a grinding and polishing with a 1- $\mu \mathrm{m}$ diamond suspension. The evolution of the interdiffusion region was evaluated by ImageJ software. The chemical concentration gradients in the interaction regions and the element mapping in IN625 were analysed by EDXS. In detail, a line scan of $25 \mu \mathrm{m}$ across the interaction area was used to record one-dimensional concentration profiles for selected chemical elements. Quantitative phase analyses were performed by XRD using Italstructures IPD300 diffractometer (IPD3000/CPS120) equipped with an Intel CPS120 detector, and a $\mathrm{Cu} \mathrm{K} \alpha(\lambda=0.1541 \mathrm{~nm})$ source of $1200 \mathrm{~W}$ with a beam size of $2 \times 8 \mathrm{~mm}$. The sample was positioned in reflection geometry with a fixed omega angle of 5 degrees. The diffraction spectra were elaborated by the Rietveld method by MAUD software (Materials Analysis Using Diffraction) [27].

\section{Results and Discussion}

Figure 1 shows the DTSC curves of the IN625 powder and on the $70 \mathrm{wt} . \% \mathrm{WC}-$ 30 wt.\% IN625 mix.

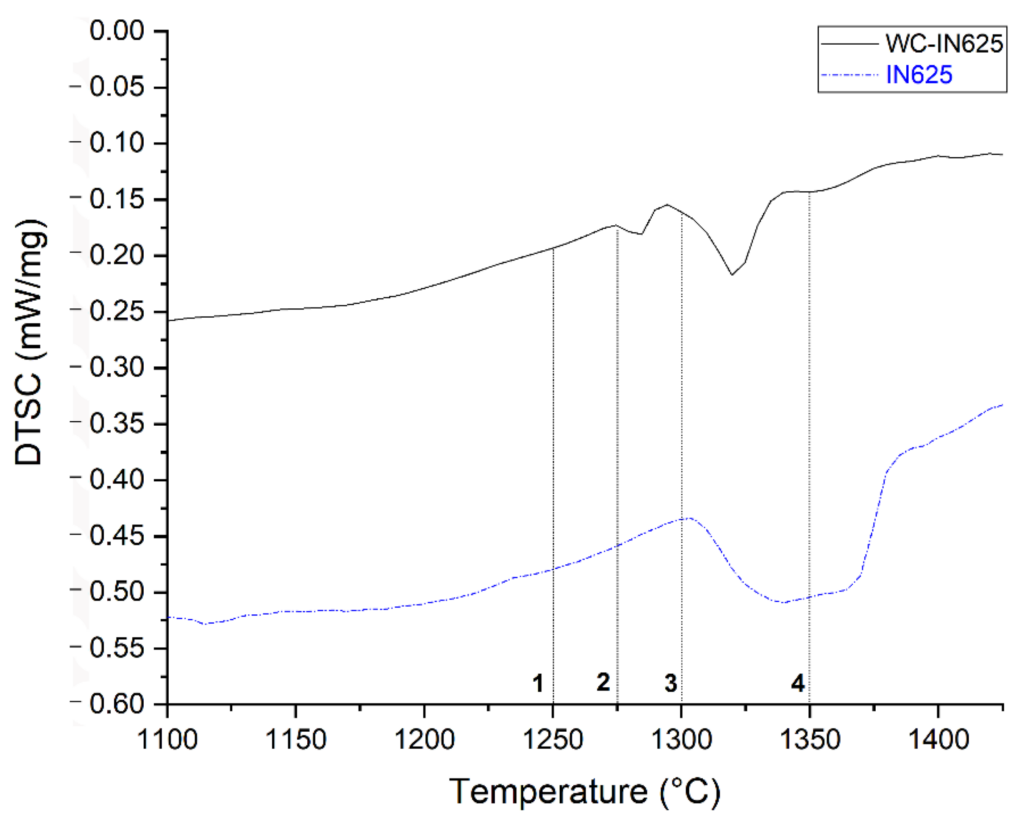

Figure 1. Differential Temperature Scanning Calorimeter (DTSC) curve of IN625 powder and of $70 \mathrm{wt} . \% \mathrm{WC}-30 \mathrm{wt} . \%$ IN625 at a heating rate of $10{ }^{\circ} \mathrm{C} / \mathrm{min}$.

The melting range of IN625 is between $1307^{\circ} \mathrm{C}$ and $1380{ }^{\circ} \mathrm{C}$, with the peak at $1361{ }^{\circ} \mathrm{C}$. In the WC-IN625 mix, two endothermic peaks were detected. The first peak started at $1278{ }^{\circ} \mathrm{C}$ and finishes at $1284{ }^{\circ} \mathrm{C}$, and could refer to an endothermic reaction between WC and IN625 or to an incipient melting of IN625 in contact with WC, enhanced by the solubilization of C. No information was available about the effect of carbon on the melting temperatures of the superalloy, but it is well known that carbon in solid solution decreases 
the melting temperature of $\mathrm{Ni}$ in the $\mathrm{W}-\mathrm{Ni}-\mathrm{C}$ phase diagram [3]. The second peak between $1311^{\circ} \mathrm{C}$ and $1332{ }^{\circ} \mathrm{C}$ refers to the melting of IN625.

Based on the DTSC results, four different sintering temperatures were selected $1250^{\circ} \mathrm{C}$, $1275{ }^{\circ} \mathrm{C}, 1300^{\circ} \mathrm{C}$ and $1350^{\circ} \mathrm{C}$. While the sintering process in cycles 1 and 2 is in a solid state, liquid-phase sintering occurs in cycle 4 . In cycle 3 , the formation of a small amount of liquid might be observed. The micrographs of the hot-compacted sample (pre-compacted) and of the sintered samples are shown in Figure 2.
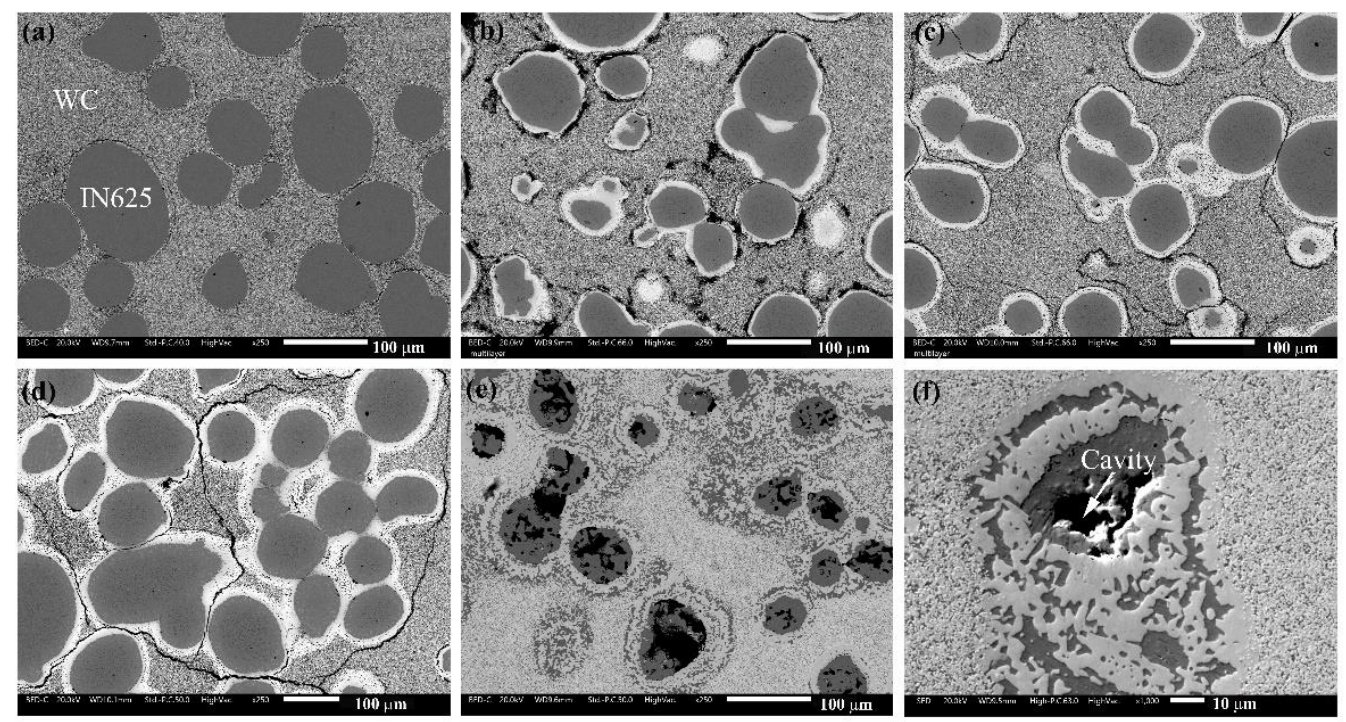

Figure 2. WC-IN625 microstructure of the pre-compacted (a), and sintered specimens at $1250{ }^{\circ} \mathrm{C}(\mathbf{b})$, $1275^{\circ} \mathrm{C}(\mathbf{c}), 1300{ }^{\circ} \mathrm{C}(\mathbf{d}), 1350{ }^{\circ} \mathrm{C}(\mathbf{e}, \mathbf{f})$.

From Figure 2 it is clearly evident that in pre-compacted form and after sintering at 1250,1275 and $1300{ }^{\circ} \mathrm{C}$, a high amount of cracks surrounded the IN625 powder due to the high difference between the WC and IN625 grain sizes. These cracks disappeared when the liquid-phase sintering occurred, as shown in Figure 2d. For the purposes of this work, large IN625 particles were selected to facilitate the analysis of the interaction between WC-IN625 leading to a material impossible to test mechanically. Figure 2 highlights that in the precompacted condition, the consolidation of the powders occurs without any reactions. Conversely, after the sintering cycles, an interdiffusion region (white area) surrounding the IN625 particles was observed, forming a shell with a thickness that increased with the increase of the sintering temperature, as shown in Figure 3.

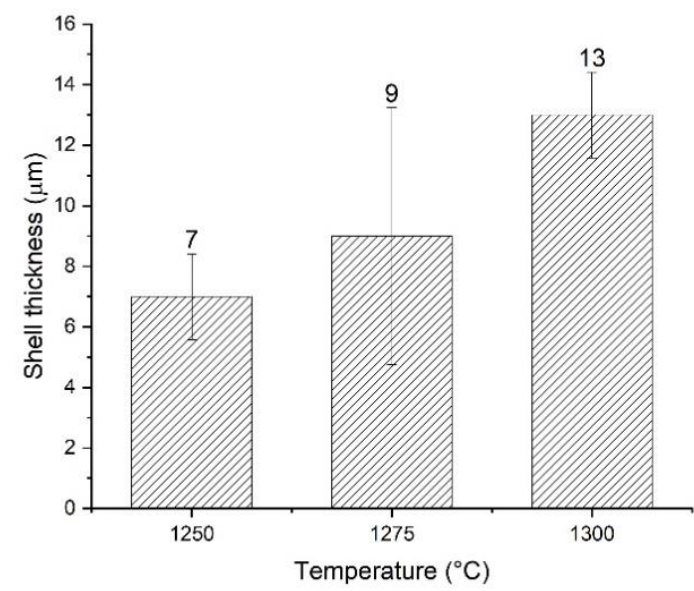

Figure 3. Shell thickness surrounding the IN625 powder after at $1250{ }^{\circ} \mathrm{C}, 1275^{\circ} \mathrm{C}$ and $1300^{\circ} \mathrm{C}$. 
A greater variation of the thickness was evident from $1275^{\circ} \mathrm{C}$ to $1300{ }^{\circ} \mathrm{C}$ than from $1250{ }^{\circ} \mathrm{C}$ to $1275^{\circ} \mathrm{C}$. This could be justified by the formation of a liquid phase at $1300^{\circ} \mathrm{C}$ that enhances the interdiffusion process. No morphological variations were observed between $1250{ }^{\circ} \mathrm{C}, 1275^{\circ} \mathrm{C}$ and $1300{ }^{\circ} \mathrm{C}$, suggesting that the interaction gave rise to the formation of the same products. This confirms that the first peak at $1284^{\circ} \mathrm{C}$ observed in the DTSC curve of WC-IN625 mixture (Figure 1) refers to local melting of IN625 in contact with $\mathrm{WC}$ and not to the formation of different phases at lower temperatures. Liquid phase sintering takes place only in cycle 4 , at the highest sintering temperature $\left(1350{ }^{\circ} \mathrm{C}\right)$ where the superalloy is completely melted. In this condition, the microstructure of the interaction region is completely different since the melted superalloy had spread to the surrounding areas (Figure 2f).

The concentration profiles of the different elements through the interaction zones between WC and IN625 in the pre-compacted condition and after the four different sintering cycles are shown in Figure 4.

a) PRE-COMPACTED

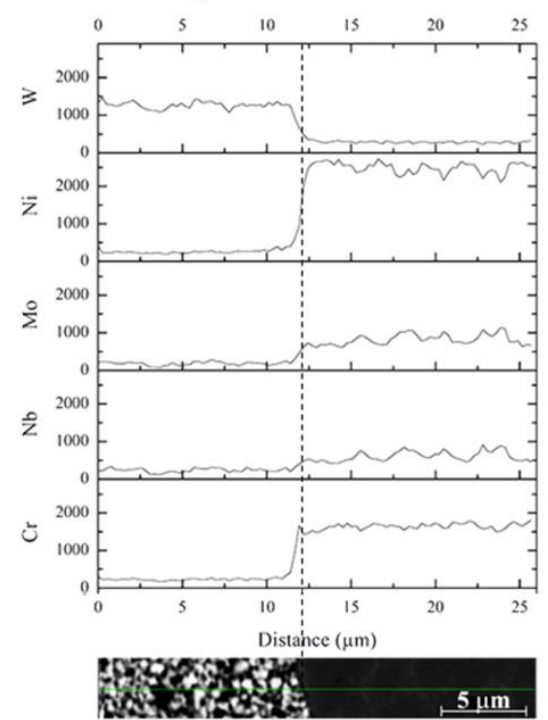

b) $1250{ }^{\circ} \mathrm{C}$

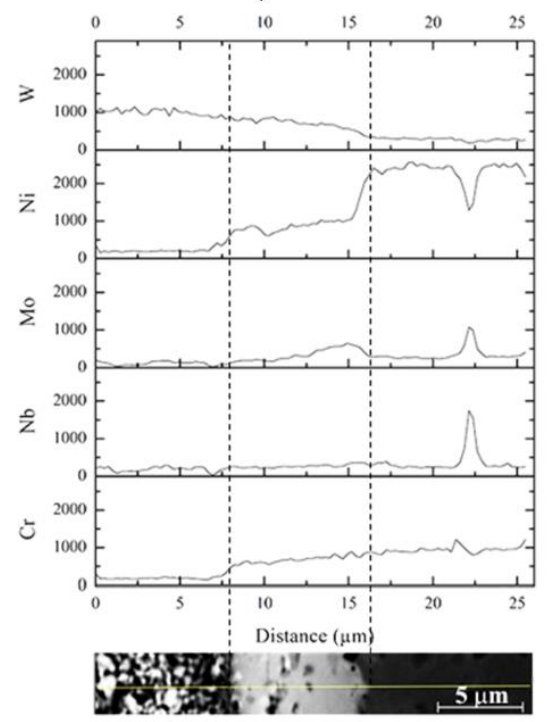

c) $1275^{\circ} \mathrm{C}$

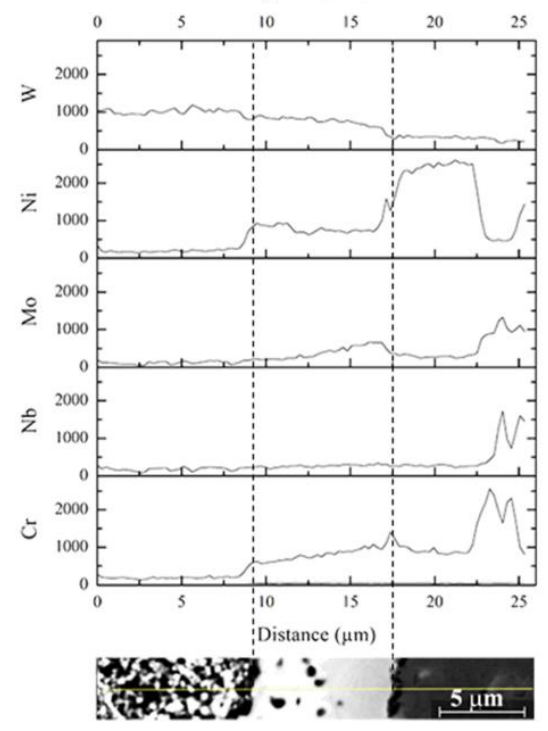

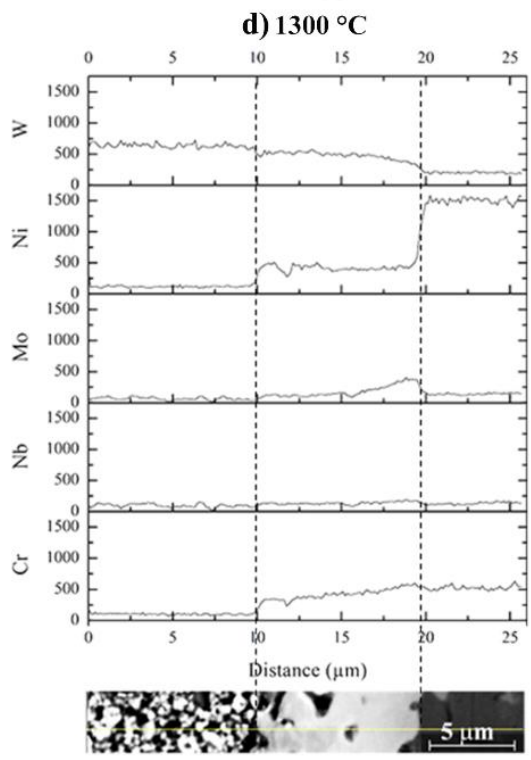

e) $1350{ }^{\circ} \mathrm{C}$

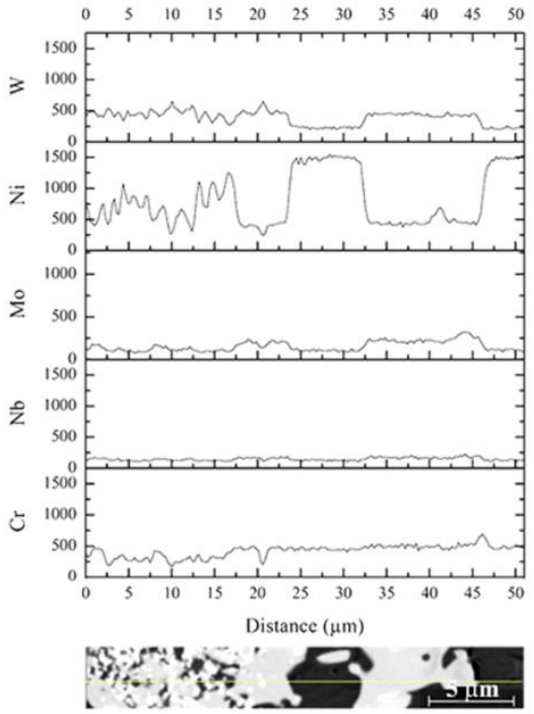

Figure 4. Line scan profiles of the different elements in the interaction area shown in the images, of WC-IN625 in the pre-compacted condition (a) and after sintering at $1250{ }^{\circ} \mathrm{C}(\mathbf{b}), 1275^{\circ} \mathrm{C}$ (c), $1300{ }^{\circ} \mathrm{C}$ (d) and $1350{ }^{\circ} \mathrm{C}(\mathbf{e})$. 
$\mathrm{Ni}, \mathrm{Cr}$, Mo and $\mathrm{Nb}$ are obviously present in the IN625 powder. However, $\mathrm{W}$ is present in the WC particles area. The variation of the $\mathrm{Cr}$, Mo and $\mathrm{Nb}$ insider IN625 particles will be analyzed later (Figure 6). Considering the interaction area between IN625 particle and WC carbides, in the pre-compacted condition, the concentration gradients are sharp, indicating that no diffusion phenomena occurred at the WC-IN625 interface. In the $1250{ }^{\circ} \mathrm{C}$ sintered specimen, an interdiffusion layer with a thickness of around $8 \mu \mathrm{m}$ formed, confirming the shell thickness reported in Figure 3. The concentration profiles displayed a continuous and gradual variation of $\mathrm{Cr}$ and $\mathrm{W}$ elements. In contrast, Mo showed a concentration peak near the IN625, and Ni drastically decreased with a stepped trend in the interaction area. The Mo amount in the interdiffusion layer was higher than that in the IN625, suggesting the formation of a Mo-rich phase. Increasing the sintering temperature up to $1300^{\circ} \mathrm{C}$, the thickness of the interaction region increased and the concentration peak of Mo near the IN625 particle was confirmed.

During sintering at $1350{ }^{\circ} \mathrm{C}$, IN625 melts and all the elements spread into the surrounding areas. The concentration profiles show that the black areas in the microstructure are rich of $\mathrm{Ni}$ (superalloy), which is different than those in the gray areas where $\mathrm{W}$ is the main element. Mo, $\mathrm{Nb}$ and $\mathrm{Cr}$ seemed to be homogeneously distributed. The Mo and $\mathrm{Cr}$ peaks in the same points highlighted the presence of a $(\mathrm{Cr}, \mathrm{Mo})$-rich phase, perhaps a $(\mathrm{Mo}, \mathrm{Cr})_{23} \mathrm{C}_{6}$ carbide.

To define the phases present after the different sintering cycles, Figure 5 shows the XRD spectra.

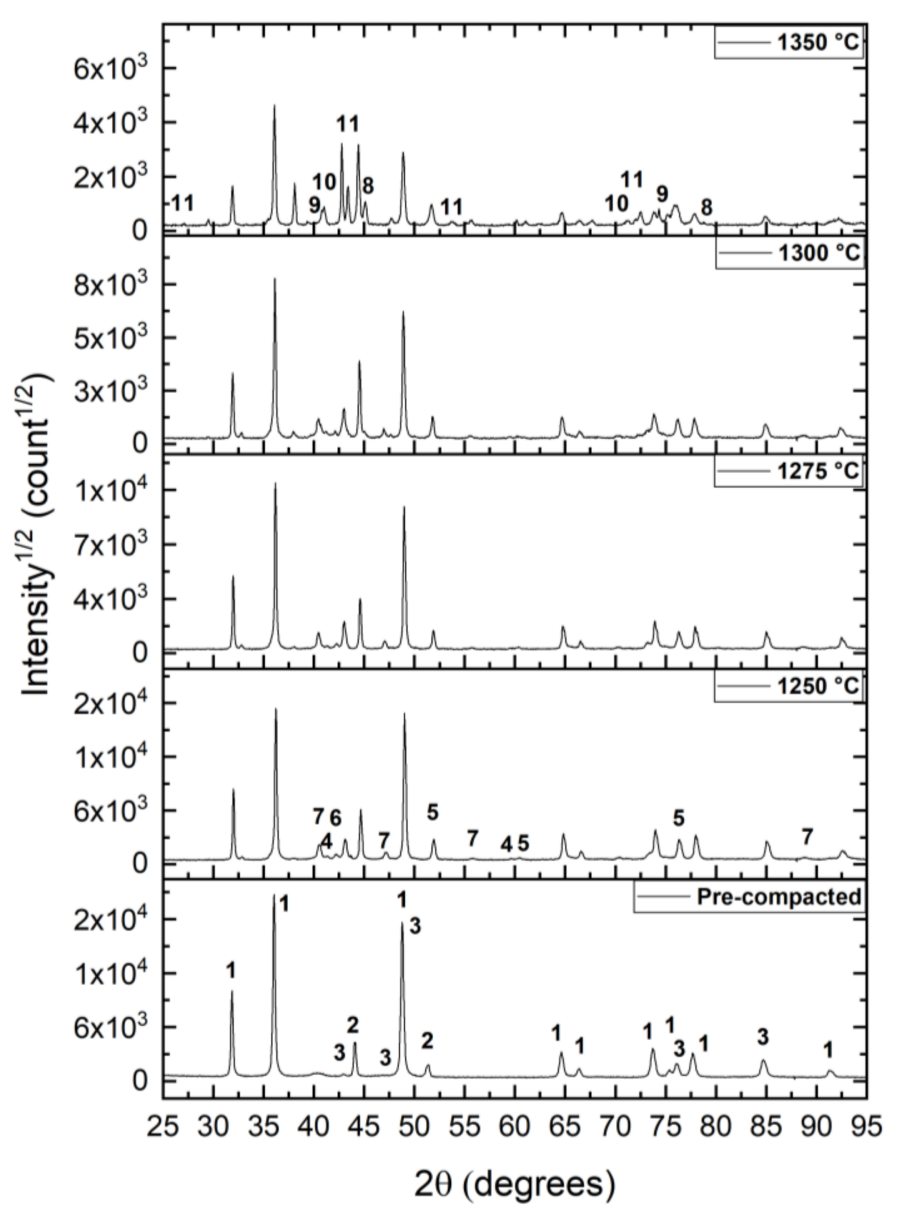

Figure 5. X-ray diffraction patterns of the $70 \mathrm{wt} \% \mathrm{WC}$ and $30 \mathrm{wt} . \%$ IN 625 mixture after compaction and sintering at different temperatures.

The results of the quantitative analysis of phases by MAUD are summarized in Table 2. 
Table 2. Quantitative analysis obtained by MAUD of the phases present in different conditions.

\begin{tabular}{|c|c|c|c|c|c|c|c|c|c|c|c|}
\hline \multicolumn{12}{|c|}{ MAUD Quantitative Analysis (vol.\%) } \\
\hline Phase & WC & $\gamma$ & $\mathrm{Ni}_{3} \mathrm{Nb}\left(\gamma^{\mathrm{II}}\right)$ & $\mathrm{NbC}$ & $\mathrm{W}_{2} \mathrm{C}$ & $(\mathrm{Cr}, \mathrm{W})$ & $(\mathrm{Cr}, \mathrm{Mo})_{23} \mathrm{C}_{6}$ & $\mathrm{Ni}_{3} \mathrm{Nb}(\delta)$ & (Mo,W) & (Mo,Nb) & $\mathrm{Ni}_{4} \mathrm{~W}$ \\
\hline Precomp & 52 & 35 & 13 & - & - & - & - & - & - & - & - \\
\hline $1250^{\circ} \mathrm{C}$ & 30 & 29 & 11 & 2 & 1 & 1 & 26 & - & - & - & - \\
\hline $1275^{\circ} \mathrm{C}$ & 26 & 26 & 14 & 2 & 2 & 1 & 29 & - & - & - & - \\
\hline $1300{ }^{\circ} \mathrm{C}$ & 20 & 30 & 16 & 2 & 2 & 1 & 29 & - & - & - & - \\
\hline $1350{ }^{\circ} \mathrm{C}$ & 10 & 22 & 10 & 8 & 2 & 9 & 9 & 7 & 10 & 5 & 8 \\
\hline
\end{tabular}

In the pre-compacted specimen $\mathrm{WC}, \gamma$ and $\gamma^{\mathrm{II}}$ are the only phases detected, confirming the absence of any significant interaction at the interface [23]. The sintering cycles promote the formation of new phases in the interaction region and in IN625. In the spectra relevant to cycles 1,2 and 3 , the detected phases are $\mathrm{WC}, \gamma, \gamma^{\mathrm{II}}, \mathrm{NbC}, \mathrm{W}_{2} \mathrm{C},(\mathrm{Cr}, \mathrm{W})$ solid solution and $(\mathrm{Cr}, \mathrm{Mo})_{23} \mathrm{C}_{6}$. The amount of these phases changes by increasing the sintering temperature: $\gamma, \mathrm{NbC}$ and $(\mathrm{Cr}, \mathrm{W})$ solid solution remain constant while the $\mathrm{W}_{2} \mathrm{C}$ and $(\mathrm{Cr}, \mathrm{Mo})_{23} \mathrm{C}_{6}$ carbides increase from $1250{ }^{\circ} \mathrm{C}$ up to $1275^{\circ} \mathrm{C}$ and remain constant at $1300^{\circ} \mathrm{C}$. In addition, the WC amount decreased and the $\gamma^{\mathrm{II}}$ content increased by increasing the sintering temperature up to $1300{ }^{\circ} \mathrm{C}$. The formation of $\mathrm{Cr}$-rich phases is deleterious in terms of corrosion resistance since $\mathrm{Cr}$ must be homogeneously distributed to form a continuous passivation film on the surface. $\mathrm{W}_{2} \mathrm{C}$ also had an embrittling phase, as observed in the WC-Co system [3]. NbC, with a small and rounded shape and a homogeneous distribution in the matrix, increased in terms of hardness and strength, as did the ordered precipitate $\gamma^{\mathrm{II}}$. After sintering at $1350{ }^{\circ} \mathrm{C}$, the amount of the mentioned phases changed and the formation of new phases, namely $\mathrm{Ni}_{4} \mathrm{~W}, \delta$ and $(\mathrm{Mo}, \mathrm{W})$ and $(\mathrm{Mo}, \mathrm{Nb})$ solid solutions occurred, favored by the melting of IN625.

Figure 6 shows the microstructural evolution and the element mapping in the IN625 particle in the pre-compacted condition and after sintering at $1250{ }^{\circ} \mathrm{C}, 1275^{\circ} \mathrm{C}, 1300^{\circ} \mathrm{C}$ and $1350{ }^{\circ} \mathrm{C}$.
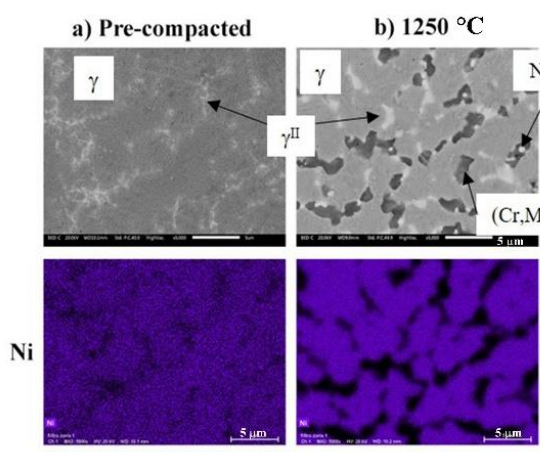

c) $1275^{\circ} \mathrm{C}$
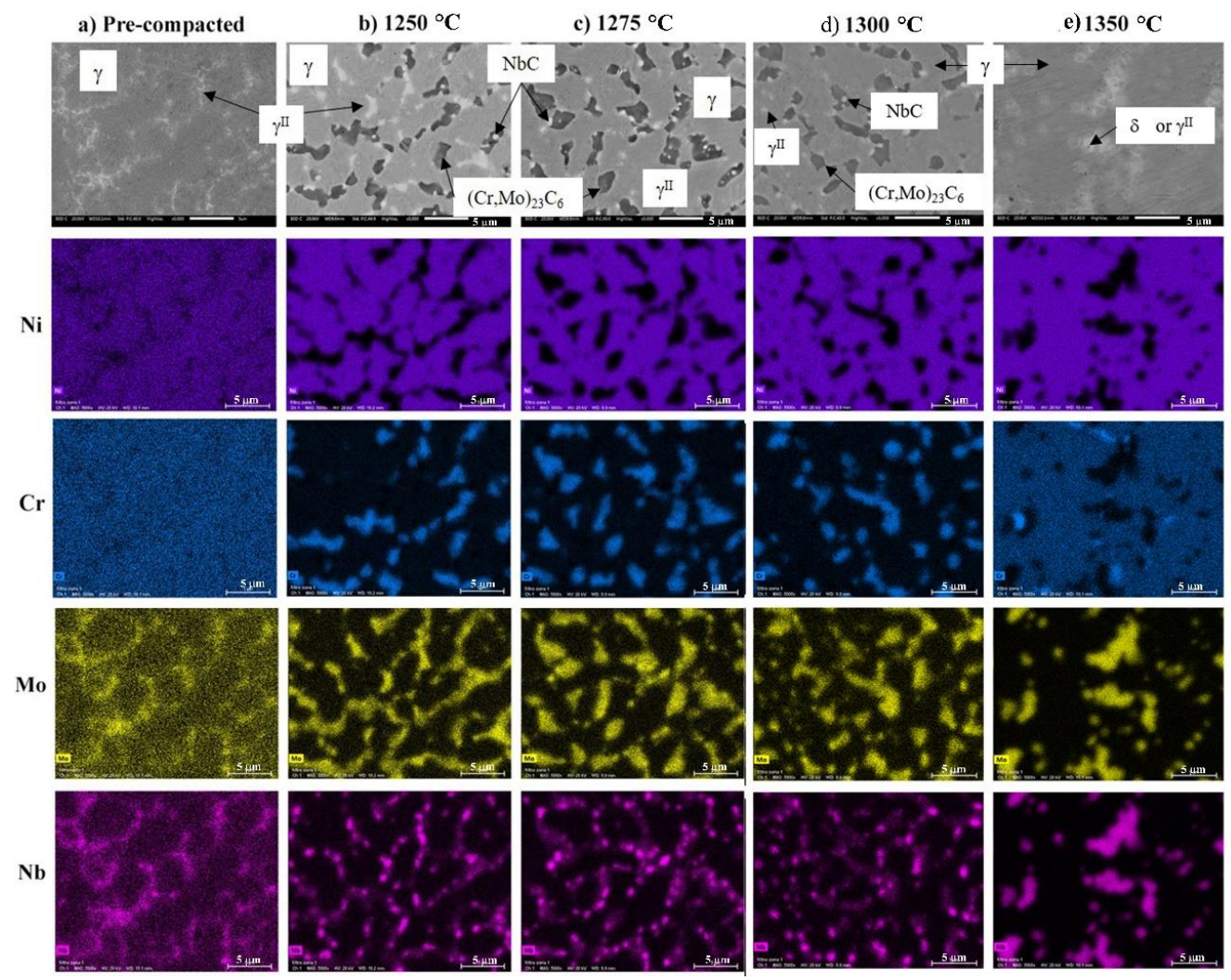

Figure 6. Microstructure evolution and element mapping of IN625 powder after pre-compacted condition (a), and after sintering at $1250{ }^{\circ} \mathrm{C}(\mathbf{b}), 1275^{\circ} \mathrm{C}(\mathbf{c}), 1300{ }^{\circ} \mathrm{C}(\mathbf{d})$ and $1350{ }^{\circ} \mathrm{C}(\mathbf{e})$. 
Based on the XRD results (Table 2) and on the element mapping, it is possible to define the phase in IN625 in the different sintering conditions. The sintering process leads to a decrease of elements dissolved in the face centered cubic (fcc) $\gamma$ matrix and to the precipitation of $\mathrm{NbC}$ and $(\mathrm{Mo}, \mathrm{Cr})_{23} \mathrm{C}_{6}$ carbides in different sintering conditions [16-22]. $\mathrm{NbC}$ is rounded and homogeneously distributed in the matrix. The formation of MC and $\mathrm{M}_{23} \mathrm{C}_{6}$ carbides was caused by the decomposition of $\mathrm{WC}$ in $\mathrm{W}_{2} \mathrm{C}$ and $\mathrm{C}$, and the latter may react with $\mathrm{Nb}, \mathrm{Cr}$ and Mo. When the liquid phase forms, only the fcc $\gamma$ matrix, $\gamma^{\mathrm{II}}$ and/or the $\delta$ phase were detected. With element mapping, it was not possible to distinguish from $\gamma^{\mathrm{II}}$ and $\delta$ since both are characterized by the same chemical composition and differ only in term of crystalline structure.

The transformations occurring during the sintering processes at the different temperatures affected the lattice parameter of the fcc $\gamma$ matrix, as reported in Table 3.

Table 3. Lattice parameter (a) of $\gamma$ fcc (face centered cubic) crystal structure in the different conditions.

\begin{tabular}{cccccc}
\hline \multirow{2}{*}{ Ni-fcc } & Pre-Compacted & $\mathbf{1 2 5 0}{ }^{\circ} \mathbf{C}$ & $\mathbf{1 2 7 5}{ }^{\circ} \mathbf{C}$ & $\mathbf{1 3 0 0}{ }^{\circ} \mathbf{C}$ & $\mathbf{1 3 5 0}{ }^{\circ} \mathbf{C}$ \\
\hline $\mathrm{a}_{\gamma}$ & 3.557 & 3.528 & 3.532 & 3.537 & 3.548 \\
\hline
\end{tabular}

In pre-compacted conditions, the lattice parameter of the $\gamma$ is $3.557 \AA$. The sintering process and the $\mathrm{C}$ diffusion into IN625 promoted the precipitation of $\mathrm{Cr}$, Mo and $\mathrm{Nb}$ carbides that justified the decrease of the $\gamma$ lattice parameter at $1250{ }^{\circ} \mathrm{C}[28,29]$. The increase in the sintering temperature from $1250{ }^{\circ} \mathrm{C}$ to $1300{ }^{\circ} \mathrm{C}$ brings about increased $\gamma$ lattice parameters due to the dissolution of WC and the consequent $W$ enrichment of $\gamma$. In the liquid-phase sintering, the dissolution of a high amount of WC into a liquid phase led to the final enrichment of $\mathrm{W}$ into $\gamma$ and the precipitation of $\mathrm{Ni}_{4} \mathrm{~W}$.

From these results, it is clear that the effect of $\mathrm{Cr}$ and Mo on the solid solution hardening of the $\gamma$ matrix decreased as the sintering temperatures increased. Nevertheless, $\mathrm{W}$ is a solid solution strengthening element. For this reason, the higher amount of $\mathrm{W}$ in solid solution in the $\gamma$ matrix and the precipitation of $\gamma^{\mathrm{II}}$ and $\mathrm{NbC}$ are expected to increase the strength of the superalloy through solid solution and precipitation hardening, respectively.

\section{Conclusions}

The principal motivation for this work was to study the interaction between WC and IN625 superalloy to produce a Co-free cemented carbide with higher temperature strength and corrosion/oxidation resistance with respect to the conventional material. Preliminary analyses of the interaction between WC and IN625 during thermal cycles simulating sintering at temperatures between $1250{ }^{\circ} \mathrm{C}$ and $1350{ }^{\circ} \mathrm{C}$ were carried out. The results of this work allow for the following conclusions.

- Sintering at temperature up to $1300^{\circ} \mathrm{C}$. No liquid phase is formed. The interaction between WC and IN625 brings about the formation of $\mathrm{W}_{2} \mathrm{C},(\mathrm{Mo}, \mathrm{Cr})_{23} \mathrm{C}_{6}$ and solid solution $(\mathrm{Cr}, \mathrm{W})$. Increasing the sintering temperature, $(\mathrm{Cr}, \mathrm{W})$ solid solution remains constant and the $\mathrm{W}_{2} \mathrm{C}$ and $(\mathrm{Cr}, \mathrm{Mo})_{23} \mathrm{C}_{6}$ carbides increase from $1250{ }^{\circ} \mathrm{C}$ up to $1275{ }^{\circ} \mathrm{C}$; above this temperature, they remain constant. Obviously, due to the diffusion process, the WC content decreases by increasing the sintering temperature.

- Sintering at $1350{ }^{\circ} \mathrm{C}$. A liquid phase sintering forms that enhances the interaction between the constituents of the powder mix. Additional phases are formed, namely $(\mathrm{Mo}, \mathrm{W})$ and $(\mathrm{Mo}, \mathrm{Nb})$ solid solutions, and the intermetallic $\mathrm{Ni}_{4} \mathrm{~W}$ phase.

- In the IN625 microstructure, the sintering process leads to a decrease of solute contents in the fcc $\gamma$ matrix and the precipitation of $\mathrm{NbC}$ and $(\mathrm{Mo}, \mathrm{Cr})_{23} \mathrm{C}_{6}$ carbides under the investigated sintering conditions. An increased sintering temperature up to $1275{ }^{\circ} \mathrm{C}$ promotes the precipitation of $(\mathrm{Mo}, \mathrm{Cr})_{23} \mathrm{C}_{6}$, while the amount of $\mathrm{NbC}$ remains constant. No composition variation of both carbides were observed when the sintering temperature was increased from $1275^{\circ} \mathrm{C}$ and $1300{ }^{\circ} \mathrm{C}$. In addition, the $\gamma$ amount remains 
quite constant and $\gamma^{\mathrm{II}}$ content increases by increasing the sintering temperature up to $1300{ }^{\circ} \mathrm{C}$. When liquid-phase formation occurs, only the fcc $\gamma$ matrix, $\gamma^{\mathrm{II}}$ and $\delta$ phase were detected.

Neither mechanical tests nnoroxidation tests were carried out in this work. As such, the specimens must be produced by using fine IN625 particles to achieve a homogenous distribution of the metallic matrix in the sintered microstructure of the modified hard metal. However, the following conclusions can be drawn about the possible effect of the microstructural constituents produced during the sintering cycles:

1. $\gamma^{\mathrm{II}}$ and $\mathrm{NbC}$ are expected to affect mechanical properties positively by precipitation hardening;

2. The Cr-rich phases may also improve mechanical properties, but they should have a negative effect on the oxidation/corrosion resistance;

3. $\mathrm{W}_{2} \mathrm{C}$ is an embrittling phase in WC-Co;

4. No reference in the literature was found about the effect of the $(\mathrm{Mo}, \mathrm{W})$ solid solution, $(\mathrm{Mo}, \mathrm{Nb})$, intermetallic $\mathrm{Ni}_{4} \mathrm{~W}$ phase, and $\delta$.

Work is in progress to investigate these effects in a hard metal with a fine microstructure obtained by dispersing WC homogeneously in the metallic matrix. The results of the present work indicate that a low sintering temperature is needed to reduce the interaction between the two constituents. However, it will be interesting to investigate the properties of the material sintered at the highest temperature to verify the effect of the new phases and of their distribution in the microstructure resulting from the use of a fine IN625 powder.

Author Contributions: L.E., A.M., and M.P. conceptualized the research and contributed to data analysis, discussion of results, and paper writing. All authors have read and agreed to the published version of the manuscript.

Funding: This research received no external funding.

Conflicts of Interest: The authors declare no potential conflicts of interest with respect to the research, authorship, and/or publication of this article.

\section{References}

1. Brookes, K.J.A. Hardmetals and other Hard Materials; Metal Powder Industries Federation: Princeton, NJ, USA, 1992.

2. Santhanam, A.T.; Tierney, P.; Hunt, J.L. Properties and Selection: Nonferrous Alloys and Special Purpose Materials; ASM International: Materials Park, OH, USA, 1990.

3. Upadhyaya, G.S. Cemented Tungsten Carbides: Production, Properties, and Testing; Noyes Publications: Park Ridge, NJ, USA, 1998.

4. German, R.M. Sintering Theory and Practice; John Wiley \& Sons, Inc.: New York, NY, USA, 1996.

5. Grilli, M.; Bellezze, T.; Gamsjäger, E.; Rinaldi, A.; Novak, P.; Balos, S.; Piticescu, R.; Ruello, M. Solutions for Critical Raw Materials under Extreme Conditions: A Review. Materials 2017, 10, 285. [CrossRef] [PubMed]

6. Penrice, T.W. Alternative Binder for Hard Metals. J. Mater. Shaping Technol. 1987, 5, 35-39. [CrossRef]

7. Bhaumik, S.K.; Upadhyaya, G.S.; Vaidya, M.L. Effect of Ti(C,N) addition on sintering behavior and properties of binder-modified WC-10Co cemented carbide. J. Mater. Sci. 1994, 29, 54-60. [CrossRef]

8. Roebuck, B.; Bennett, E.G.; Almond, E.A. Partitioning of molybdenum between carbide and binder phase in WC/Ni cemented carbides infiltrated with Ni-Cr-Mo alloys. J. Mater. Sci. Lett. 1986, 5, 473-474. [CrossRef]

9. Gonzalez, G.; Echeberria, J.; Sanchez, J.M.; Castro, F. WC-(Fe,Ni,C) Hardmetals with improved toughness through isothermal heat treatments. J. Mater. Sci. 1995, 30, 3435-3439. [CrossRef]

10. Waldorf, D.; Liu, S.; Stender, M.; Norgan, D. Alternative binder carbide tools for machining superalloys. In Proceedings of the International Conference on Manufacturing Science and Engineering, Evanston, IL, USA, 7-10 October 2008.

11. Tracey, V.A. Nickel in Hardmentals. Int. J. Refract. Hard. Met. 1992, 11, 137-149. [CrossRef]

12. Gabriel, A.; Pastor, H.; Deo, D.M.; Basu, S.; Allibert, C.H. New experimental data in the C-Fe-W, C-Co-W, C-Ni-W, C-Fe-Ni-W and C-Co-Ni-W cemented carbides systems and their application to sintering conditions. Int. J. Refract. Hard. Met. 1986, 5, $215-221$.

13. Guillermet, A.F. Co-Fe-Ni-W-C phase diagram: A thermodynamic description and calculated sections for (Co-Fe-Ni) bonded cemented WC tools. Z. Metallkd. 1989, 80, 83-94.

14. Mankins, W.L.; Lamb, S. Nickel and Nickel Alloys. In Properties and Selection: Nonferrous Alloys and Special-Purpose Materials, 2nd ed.; ASM International: Materials Park, OH, USA, 1990; pp. 1362-1404.

15. Motitschka, R.; Ettmayer, P.; Kny, E. Constitution of the Systems Co-Cr-W-C and Ni-Cr-W-C in the Cobalt and Nickel Corner. In Proceedings of the 12th International Plansee Seminar, Reutte, Austria, 8-12 May 1989; pp. 863-868. 
16. Shankar, V.; Bhanu Sankara Rao, K.; Mannan, S.L. Microstructure and mechanical properties of Inconel 625 superalloy. J. Nucl. Mater. 2001, 288, 222-232. [CrossRef]

17. ASM International. Properties and Selection: Nonferrous Alloy and Special-Purpose Materials, 2nd ed.; ASM International: Materials Park, OH, USA, 1992; pp. 1362-1370.

18. Floreen, S.; Fuchs, E.G.; Yang, J.W. The Metallurgy of Alloy 625. In Superalloy 718, 625, 706 and Various Derivatives; Loria, E.A., Ed.; The Minerals, Metals \& Materials Society: Pittsburgh, PA, USA, 1994; pp. 13-37.

19. Frank Rizzo, J.; Radavich, J. Microstructure characterization of PM 625-type materials. In Superalloy 718, 625, 706 and Various Derivatives; Loria, E.A., Ed.; The Minerals, Metals \& Materials Society: Pittsburgh, PA, USA, 1991; pp. $297-308$.

20. Petrzak, P.; Kowalski, K.; Blicharski, M. Analysis of phase transformations in Inconel 625 alloy during annealing. In Proceedings of the XXIII Conference on applied crystallography, Krynica Zdrój, Poland, 20-24 September 2015.

21. Dupont, J.N. Solidification of an Alloy 625 weld overlay. Metall. Mater. Trans. A. 1996, 27, 3612-3620. [CrossRef]

22. Cieslak, M.J. The solidification behavior of an Alloy 625/718 variant. In Superalloy 718, 625, 706 and Various Derivatives; Loria, E.A., Ed.; The Minerals, Metals \& Materials Society: Pittsburgh, PA, USA, 1991; pp. 71-80.

23. Nguyen, Q.B.; Zhu, Z.; Chua, B.W.; Zhou, W.; Wei, J.; Nai, S.M.L. Development of WC-Inconel composites using selective laser melting. Arch. Civ. Mech. Eng. 2018, 18, 1410-1420. [CrossRef]

24. Huebner, J.; Kata, D.; Rutkowski, P.; Petrzak, P.; Kusiński, J. Grain-Boundary Interaction between Inconel 625 and WC during Laser Metal Deposition. Materials 2018, 11, 1797. [CrossRef] [PubMed]

25. Huebner, J.; Rutkowski, P.; Kata, D.; Kusinski, J. Microstructural and Mechanical Study of Inconel 625-Tungsten Carbide Composite Coatings Obtained by Powder Laser Cladding. Arch. Metall. Mater. 2017, 2, 531-538. [CrossRef]

26. Janicki, D.; Musztyfaga, M. Direct Diode Laser Cladding of Inconel 625/WC Composite Coatings. J. Mech. Eng. $2018,62,363-372$. [CrossRef]

27. Rietveld, H.M. A profile refinement method for nuclear and magnetic structures. J. Appl. Crystallogr. 1969, 2, 65-71. [CrossRef]

28. Machado, I.F.; Girardini, L.; Lonardelli, I.; Molinari, A. The study of ternary carbides formation during SPS consolidation process in the WC-Co-steel system. Int. J. Refract. Met. Hard Mater. 2009, 27, 883-891. [CrossRef]

29. Li, S.; Wei, Q.; Shi, Y.; Zhu, Z.; Zhang, D. Microstructure Characteristics of Inconel 625 Superalloy Manufactured by Selective Laser Melting. J. Mater. Sci. Technol. 2015, 31, 946-952. [CrossRef] 